\title{
Some Variables Associated with Psychologists' Appraisal of Psychotherapy in Argentina
}

\author{
Horacio Daniel García \\ Universidad Nacional de San Luis, Argentina
}

\begin{abstract}
The purpose of this research is to provide information about the state of psychotherapy in Argentina, as well as to study some variables involved in psychologists' evaluation of psychotherapy. A survey of 14 items was elaborated ad-hoc for this purpose, and administered to 226 psychologists from all over the country by mail and, in some cases, personally. Results suggest that the predisposition to apply techniques from different frameworks is associated with the amount of experience and with the perception of a bias concerning other theoretical focuses, although it is not related to the evaluation of the state of psychotherapy. On the other hand, in the view of psychologists, personal aspects of the therapeutic relationship are believed to be the most important factor in patients' change and effective progress.
\end{abstract}

Keywords: psychologists, attitudes, psychotherapy, valuation

\begin{abstract}
Esta investigación intenta aportar información acerca del estado de la psicoterapia en Argentina y de algunas variables relacionadas con la valoración de la psicoterapia por los psicólogos. El estudio utilizó una encuesta de 14 ítems, diseñada ad-hoc, que se administró a 226 psicólogos de todo el país por medio de correo electrónico y, en algunos casos, personalmente. Los resultados indican que la predisposición a incorporar técnicas de distintos enfoques se relaciona con los años de experiencia y con la percepción de la existencia de un sesgo respecto de los aportes de otros enfoques teóricos, en tanto que no se encontró evidencia de su relación con la valoración del estado de la psicoterapia. Por otro lado, se encontró que los psicólogos atribuyen el cambio y el progreso efectivo de los pacientes principalmente a los aspectos personales de la relación terapéutica. Palabras clave: psicólogos, actitudes, psicoterapia, valoración
\end{abstract}

Address correspondence to Horacio Daniel García, Psicología General de la Licenciatura en Fonoaudiología, Universidad Nacional de San Luis, Ejército de los Andes 950, San Luis, Argentina. C. P. 5700. Phone: 02652 - 443928. E-mail: hdgarcia@unsl.edu.ar 
Psychology originally emerged in the attempt to find explanations and effective Interventions for a series of observable incidents that traditional medicine could neither explain nor deal with. Subsequently, two important wars guaranteed the development of psychology. Within this context, psychology could elaborate explanatory theories and, from this perspective, propose techniques to address the aforementioned events with some success.

The enthusiasm of society and, mainly, of the psychologists of that period was sustained by the limitations in the development of medicine, for which it was hard to explain the symptomatology associated with mental disorders. Society's complicit patience increased this enthusiasm, as society did not demand significant results from psychological treatments. If traditional science could not respond, why demand better results from psychology, which was a new science?

The significant transformation of the socio-politicaleconomic area has affected each and every one of the areas that comprise this macro-system, this network within which the human race is set. The demand for the effectiveness of psychotherapy has increased exponentially along with the speed of these changes, although the theoretical development of psychology does not seem to have accompanied this demand.

Psychotherapy is currently evolving under high pressure because of demands of effectiveness. Society, the states, and the very psychologists who practice psychotherapy make demands on and constantly appraise its achievements. Within this context, it is interesting to investigate psychologists' perception of their practice.

Psychotherapy and its advancement have been enriched by the large number of approaches and theoretical models. The diversity and profusion of great thinkers has led to the exploration of different aspects and viewpoints of a common problem: mankind. However, such plurality has not contributed to the development of psychotherapy, mainly because of the mutual discredit of the contributions of the different theories. This outlook is shared by Karasu (1986), who believed that sectarism (the belief in the superiority of one's perspective over that of others) is an obstacle for the comprehension of models and, hence, for psychotherapeutic effectiveness. A typical example of this disparagement of other contributions is found in Eysenck (1952), who, in relation to psychotherapy, seriously questioned the usefulness of nonbehavioral treatments, claiming that the results of such work methodologies were inferior to spontaneous remission. More recently, this author stated that psychoanalysis as a treatment method does not work, and that Freud had made psychology and psychiatry go back 50 years, preventing the development of theories and methods considered scientific (Eysenck, 1994).

According to Milton Erickson, psychotherapy should be formulated to discover the individual's needs instead of trying to adapt the person to fit the theory (Opazo, 2001). However, if one observes the different therapeutic approaches, one can see that most therapists usually use a certain approach provided by their theoretical framework and they usually are blind to other orientations and conceptualizations that could possibly provide more effective intervention procedures (Goldfried, 1985).

In the decade of the 1980s, Karasu estimated that there were at least 400 different approaches to psychotherapy that were created in the hundred years since the development of the science (Ford \& Urban, 1998). Although there is currently some concern about finding ways to unite the criteria of the different models in order to satisfy the growing demand, the diverse approaches to therapeutic methods are still completely dispersed.

Nowadays, professionals openly question the premise that states that one's theoretic model "can explain everything." Questions, objections, and, especially, a critical stance have led to blurring the artificial boundaries between theories, promoting intercommunication and, hence, theories are coming closer. In the decade of the 1980s, Larson (1980) noted that nearly $65 \%$ of the therapists acknowledged that they included contributions from other therapeutic approaches other than their own framework in their practice. All this reflects therapists' ever more specific demand for models that allow them to incorporate strategies and techniques that are increasingly effective.

In Latin American countries, as in Spain, the profession of the psychologist has been widely accepted and therefore, demanded. General phenomena such as globalization and the biotechnological advances are affecting the way that new generations think and behave (Kohlbercher, 1998). According to the studies of Jiménez, Florenzano, Buguñá, Sarnoff, and Vega (1991) and Buguñá (1993), in Chile, the increasing demand for psychotherapy does not seem to correspond to the number of therapists "formed" or who have enough training to satisfy the demand.

Alarcón (2002) stated that "current Latin American psychology presents a clearly scientific profile; speculative psychology is history, and along with it, the old prejudice about the impossibility of quantifying, explaining, and predicting human behavior" (pp. 211-212). However, in this context, there are few studies that provide data about psychotherapists' choices, either of their theoretical models and the techniques they use, and the beliefs associated with their practice. Hence, the need to analyze these factors to determine the state of psychotherapy, especially in Argentina. I propose a descriptive study at an exploratory level in order to gather information about who is working in psychotherapy.

The purpose of this study is threefold: (a) to explore the possible relation between the participants' professional seniority and their willingness to incorporate techniques from different theoretical approaches; (b) to explore the potential relation between the participants' perception of the current state of psychotherapy in Argentina and their age; and (c) to analyze the possible relation between participants' perception of the current state of psychotherapy in Argentina and their likelihood of resorting to techniques from a theoretical framework other than their own. 


\section{Method}

\section{Participants}

The sample was made up of 226 psychologists living in Argentina (160 women and 66 men). This is a nonprobabilistic sample, as the survey was sent to a considerably higher number of professionals and only those who responded are included in the sample. The inclusion criteria were to be a psychologist and to live in Argentina.

\section{Instrument and Procedure}

A 14-item survey was created to explore participants' opinions. There were three closed items (yes/no/maybe responses), five multiple choice items, two Likert-type formatted items, and four open questions, to allow respondents to express aspects not contemplated in the former items. Concerning reliability, the survey obtained a provisional (as it will be improved in the future) Cronbach's alpha of .67.

The survey was administered during the months of March to December, 2004. As the scope of the survey was national, in 175 cases, it was administered by Internet. The remaining 91 surveys were handed out personally.

\section{Results}

As can be seen in Table 1, the variable age was categorized in order to analyze possible relations with the psychologists' opinion of the current state of psychotherapy. The categorization criterion was to maintain age intervals with approximately the same number of cases and therefore, the same percentiles. Out of the entire sample, $34.51 \%$ thought that the current state of psychotherapy is bad; $41.59 \%$ stated that it is regular, $17.69 \%$ reported it as good, and $6.19 \%$ as very good. The negative perception of the current state of psychotherapy was shared by $76.1 \%$ of the total sample.

The contingency table (Table 1) shows that the opinion of the state of psychotherapy in Argentina is distributed homogeneously for the different age categories. However,
I decided to continue the analysis in order to determine whether these variables are related. In view of the value of Somers' test $(d=.038, p=.511)$, the assumption that the psychologists' age was related to their perception of the current state of psychotherapy was rejected (see Table 2).

Table 2

Somers'd Test Values between Variables Age and Opinion about the Current State of Psychotherapy

\begin{tabular}{llc}
\hline & & Value \\
\hline & $\begin{array}{l}\text { Symmetric } \\
\text { Age in categories. }\end{array}$ & .038 \\
Somers' $d$ & $\begin{array}{l}\text { Dependent } \\
\text { Opinion of Current State of } \\
\end{array}$ & .041 \\
& $\begin{array}{l}\text { Psychotherapy. } \\
\text { Dependent }\end{array}$ & .036 \\
\hline
\end{tabular}

Note. All $p \mathrm{~s}=.511$.

As shown in Table 3, work experience was categorized using the same criteria as the variable age, in order to examine its possible relations with psychologists' willingness to use techniques from various frameworks. Out of the entire sample, $21.23 \%$ reported never using techniques from a different theoretical framework, $2.21 \%$ stated that they very seldom used such techniques, $47.78 \%$ said they used them occasionally, $23.45 \%$ admitted frequently using diverse techniques regardless of their theoretical framework, and $5.30 \%$ said that they always did this. The results show that willingness to incorporating techniques from different approaches is shared by $78.74 \%$ of the psychologists of the sample.

The contingency table (Table 3) shows that the frequency of the use of techniques from another framework (other than one's own framework) could be related to the professional's years of work experience. Therefore, I decided to continue the analysis to corroborate the possibility that these variables were related.

Table 1

Contingency Table of the Variables Age and Opinion about the Current State of Psychotherapy

\begin{tabular}{|c|c|c|c|c|c|c|c|c|}
\hline & & \multicolumn{5}{|c|}{ Opinion about the current state of psychotherapy } & \multicolumn{2}{|c|}{ Total } \\
\hline & & Bad & Regular & Good & Very good & Excellent & & \\
\hline \multirow[t]{4}{*}{ Age } & 21-29 years & 22 & 22 & 9 & 5 & 0 & 58 & $25.66 \%$ \\
\hline & 30-38 years & 19 & 25 & 10 & 1 & 0 & 55 & $24.33 \%$ \\
\hline & $39-49$ years & 19 & 24 & 10 & 4 & 0 & 57 & $25.22 \%$ \\
\hline & $50-83$ years & 18 & 23 & 11 & 4 & 0 & 56 & $24.79 \%$ \\
\hline \multicolumn{2}{|c|}{ Total number } & 78 & 94 & 40 & 14 & 0 & 226 & \\
\hline \multicolumn{2}{|c|}{ Total percent } & $34.51 \%$ & $41.59 \%$ & $17.69 \%$ & $6.19 \%$ & $0 \%$ & & \\
\hline
\end{tabular}


Table 3

Contingency Table of the Variables Work Experience and the Use of Techniques from Theoretical Frameworks Other than One's Own

\begin{tabular}{|c|c|c|c|c|c|c|c|c|}
\hline & & Use of & niques from th & oretical frame & rks other th & e's own & & \\
\hline & & Never & Very seldom & Occasionally & Frequently & Always & & \\
\hline Work & $0-2$ & 13 & 2 & 23 & 8 & 2 & 48 & $21.23 \%$ \\
\hline experience & $3-8$ & 14 & 1 & 33 & 10 & 5 & 63 & $27.87 \%$ \\
\hline (years) & $9-20$ & 12 & 1 & 28 & 16 & 1 & 58 & $25.66 \%$ \\
\hline & $21-53$ & 9 & 1 & 24 & 19 & 4 & 57 & $25.22 \%$ \\
\hline Total numb & & 48 & 5 & 108 & 53 & 12 & 226 & \\
\hline Total perce & & $21.23 \%$ & $2.21 \%$ & $47.78 \%$ & $23.45 \%$ & $5.30 \%$ & & \\
\hline
\end{tabular}

As shown in Table 4, according to the value of Somers' test $(d=0.131, p=.021)$, as well as the values of gamma $(\gamma=0.184, p=.021)$, the null hypothesis was rejected and I can state that work experience, in terms of years, is significantly and positively related (although the value is low) with psychologists' willingness to use techniques from theoretical frameworks other than their own.

Table 4

Somers' $d$ and Gamma Values Between Variables Work Experience and the Use of Techniques from Theoretical Frameworks Other than One's Own

\begin{tabular}{llc}
\hline & & Value \\
\hline & $\begin{array}{l}\text { Symmetric } \\
\text { Work experience. }\end{array}$ & .131 \\
Somers' $d$ & $\begin{array}{l}\text { Dependent } \\
\text { Use of techniques from theoretical } \\
\text { frameworks other than one's own. }\end{array}$ & .138 \\
Dependent & .124 \\
Gamma & & .184 \\
\hline
\end{tabular}

Note. All $p \mathrm{~s}=.021$.
According to the value of Somers' statistic ( $d=$ $-0.010, p=.875)$, the null hypothesis was accepted. Therefore, at least in this sample, the psychotherapists' opinion about the state of psychotherapy is not related to their use of techniques from a different framework (see Table 6).

Table 6

Somers'd Test Values Between the Use of Techniques from Theoretical Frameworks Other than One's Own and the Opinion about the Current State of Psychotherapy

\begin{tabular}{llr}
\hline & Value \\
\hline & $\begin{array}{l}\text { Symmetric } \\
\text { Opinion about the Current State of }\end{array}$ & -.010 \\
& $\begin{array}{l}\text { Psychotherapy. } \\
\text { Dependent }\end{array}$ & -.010 \\
& $\begin{array}{l}\text { Use of techniques from theoretical } \\
\text { frameworks other than one's own. }\end{array}$ & -.010 \\
& & \\
\hline
\end{tabular}

Note. All $p \mathrm{~s}=.875$.

Table 5

Contingency Table of the Variables the Use of Techniques from Theoretical Frameworks Other than One's Own and Opinion about the Current State of Psychotherapy

\begin{tabular}{|c|c|c|c|c|c|c|c|}
\hline & & \multicolumn{5}{|c|}{ Opinion about the current state of psychotherapy } & \multirow{2}{*}{ Total } \\
\hline & & Bad & Regular & Good & Very good & Excellent & \\
\hline \multirow{5}{*}{$\begin{array}{l}\text { Use of techniques from } \\
\text { theoretical frameworks } \\
\text { other than one's own }\end{array}$} & Never & 20 & 16 & 11 & 1 & 0 & 48 \\
\hline & Very seldom & 1 & 1 & 1 & 2 & 0 & 5 \\
\hline & Occasionally & 33 & 50 & 21 & 4 & 0 & 108 \\
\hline & Frequently & 17 & 24 & 7 & 5 & 0 & 53 \\
\hline & Always & 7 & 3 & 0 & 2 & 0 & 12 \\
\hline Total & & 78 & 94 & 40 & 14 & 0 & 226 \\
\hline
\end{tabular}


I decided to provide a section in the survey where only the psychologists who were employed in the clinical area $(n=206)$ could report which techniques they use in psychotherapy. When subsequently analyzing the data, the techniques they indicated were compared with the corresponding theoretical framework so that the variable "real combination of techniques from frameworks other than one's own" would only take on "yes/no" values. The results observed in Table 7 show that 3 out of 4 clinical psychologists (75.73\%) combine techniques from different theoretical approaches. Conversely, according to $58.25 \%$ of the participants, psychologists suffer from selective blindness that leads them to discredit or to ignore the contributions of other theoretical perspectives; $32.52 \%$ admitted the possibility, and $9.22 \%$ denied having such a bias.

In order to observe the possible relation between the variables selective blindness towards other contributions and the real combination of techniques from frameworks other than one's own, various statistical tests were performed (see Table 8 ). This relation was confirmed by Pearson's chi-square test $(\chi 2=17.043, p=.000)$ and corroborated by the Phi statistic $(\phi=0.288, p=.000)$ and the contingency coefficient $(0.276$, $p=.000)$. Therefore, the null hypothesis was rejected and the relation between the two variables can be described as of low intensity but highly significant. As this is a relation between nominal variables, the statistics observed do not specify its direction. However, when looking at the contingency table for these two variables (Table 7), we can see that the psychologists who admit having an evaluative bias have a higher tendency to combine techniques from different approaches.

In Table 9, it can be observed that $54.41 \%$ of the psychologists of the sample thought that factors related to patients' effective change are linked to personal aspects such
Table 8

Chi-Square, Phi, and Contingency Coefficient Values between the Variables Selective Blindness towards Other Contributions and Real Combination of Techniques from Frameworks Other than One's Own

\begin{tabular}{lcc}
\hline & Value & $d f$ \\
\hline Pearson's Chi-square & $17.043^{\mathrm{a} *}$ & 2 \\
Phi value & $.288^{+}$ & \\
Contingency coefficient & $.276^{+}$ & \\
\hline
\end{tabular}

Note. ${ }^{\text {a }}$ One cell $(16.7 \%)$ had an expected frequency lower than 5 . The minimum expected frequency was 4.61 .

${ }^{*} p=.000$, two-tailed asymmetrical. ${ }^{+} p=.000$ one-tailed.

as the therapeutic relationship, the therapist's style and clinical experience; $4.41 \%$ felt that only theoretical and practical aspects such as the theoretical model and the techniques determine patients' change. Lastly, $41.18 \%$ considered that the combination of the former aspects was responsible for patients' progress.

In order to determine whether the variables blindness towards other contributions and the magnitude of the change in psychotherapy are related, Pearson's chi-square test was performed. As shown in Table 10, the value obtained $\left(\chi^{2}=\right.$ $9.965, p=.041)$ allows one to reject the null hypothesis and assert that these variables are related. Similarly, the value and significance of the $\phi$ statistic $(\phi=0.221, p=.041)$ and the contingency coefficient $(.216, p=.041)$ reveal the relation between these variables as being significant and of low intensity. The contingency table (Table 9) for these variables shows that those who think that psychologists tend to ignore the contribution of other theories are more likely to consider that personal aspects are responsible for patients' effective change.

Table 7

Contingency Table of the Variables Selective Blindness towards Other Contributions and Real Combination of Techniques from Frameworks Other than One's Own

Real combination of techniques

from frameworks other than one's own

Total

Yes No

\begin{tabular}{|c|c|c|c|c|c|c|}
\hline \multirow{6}{*}{$\begin{array}{l}\text { Selective } \\
\text { blindness } \\
\text { towards other } \\
\text { contributions }\end{array}$} & \multirow{2}{*}{ Yes } & Count & 103 & 17 & \multirow{2}{*}{120} & \multirow{2}{*}{$58.25 \%$} \\
\hline & & Residual * & 4.0 & -4.0 & & \\
\hline & \multirow{2}{*}{ Perhaps } & Count & 43 & 24 & \multirow{2}{*}{67} & \multirow{2}{*}{$32.52 \%$} \\
\hline & & Residual * & -2.7 & 2.7 & & \\
\hline & \multirow{2}{*}{ No } & Count & 10 & 9 & \multirow{2}{*}{19} & \multirow{2}{*}{$9.22 \%$} \\
\hline & & Residual * & -2.5 & 2.5 & & \\
\hline Total number & & & 156 & 50 & 206 & \\
\hline Total percent & & & $75.73 \%$ & $24.27 \%$ & & \\
\hline
\end{tabular}

* Corrected standardized residuals 


\begin{tabular}{|c|c|c|c|c|c|c|c|}
\hline & & & \multicolumn{3}{|c|}{$\begin{array}{l}\text { Selective blindness towards } \\
\text { other contributions }\end{array}$} & \multicolumn{2}{|c|}{ Total } \\
\hline & & & Yes & Perhaps & No & & \\
\hline & \multirow{2}{*}{ Only personal aspects } & Count & 70 & 33 & 8 & \multirow{2}{*}{111} & \multirow{2}{*}{$54.41 \%$} \\
\hline & & Residual * & 1.6 & -1.0 & -1.1 & & \\
\hline \multirow{4}{*}{$\begin{array}{l}\text { Amount of } \\
\text { change in } \\
\text { psychotherapy }\end{array}$} & \multirow{2}{*}{ Only theoretical-practical aspects } & Count & 5 & 1 & 3 & \multirow{2}{*}{9} & \multirow{2}{*}{$4.41 \%$} \\
\hline & & Residual * & -.1 & -1.4 & 2.5 & & \\
\hline & \multirow{2}{*}{$\begin{array}{l}\text { Combination of theoretical-practical } \\
\text { and personal aspects }\end{array}$} & Count & 43 & 33 & 8 & \multirow{2}{*}{84} & \multirow{2}{*}{$41.18 \%$} \\
\hline & & Residual * & -1.6 & 1.6 & .1 & & \\
\hline Total & & & 118 & 67 & 19 & 204 & \\
\hline
\end{tabular}

* Corrected standardized residuals

Table 10

Chi-Square, Phi, and Contingency Coefficient Values between the Variables Selective Blindness towards Other Contributions and Amount of Change in Psychotherapy

\begin{tabular}{lll}
\hline & Value & $d f$ \\
\hline Pearson's Chi-square & $9.965^{\text {a } *}$ & 44 \\
Phi & $.221^{+}$ & \\
Contingency coefficient & $.216^{+}$ & \\
\hline
\end{tabular}

Note. ${ }^{\text {a }}$ Two cells $(22.2 \%)$ had an expected frequency lower than 5. The minimum expected frequency was 0.84 .

$* p=.041$, two-tailed asymmetric. ${ }^{+} p=.041$, one-tailed.

\section{Discussion}

For the Chilean researcher, Opazo (2001), dissatisfaction with the results obtained in psychotherapy is an indicator of the crisis it is going through. According to this author, this dissatisfaction is also a factor that promotes integration movements in psychotherapy. The results obtained reveal the current critical attitude of psychologists about psychotherapy. Three out of four participants share a negative view of psychotherapy, although it is worth mentioning that this perception is not related to the participants' age.

Fernández Álvarez (1996) noted that a kind of spontaneous eclecticism was emerging, which tends to favor the use of any strategy that helps the patients. Most of the psychologists who participated in this study agreed about using of technical resources from different frameworks to achieve the desired therapeutic goals. With varying frequency, approximately 8 out of 10 psychologists have incorporated techniques from different approaches in their treatments. This result supports the research performed by Larson (1980) and Watkins (1986), who indicated that almost $65 \%$ of the psychotherapists admitted that they included contributions from other therapeutic approaches in their practice. On the other hand, work experience, in terms of years of activity, was found to be related to incorporating techniques from theoretical frameworks other than one's own. Hence, the more years of practice, the higher the predisposition to incorporate techniques from different approaches. There is no evidence suggesting that a negative perception of the state of psychotherapy is related to this tendency to use techniques from a different theoretical framework.

One of the methodological obstacles in psychotherapy is therapists' emotional commitment to their theoretical approach (Opazo, 2001). This emotional commitment is maintained by the typical attributional style that leads one to impute successes to one's particular paradigm. As I suspected the presence of this bias in the participants of the sample, especially the one referring to the use of different techniques, in another section of the survey, participants were asked to name the techniques they generally used in psychotherapy. These techniques were then classified according to the theoretical framework of each psychologist, obtaining two groups of analysis and thus discriminating between those who actually did and those who did not incorporate such techniques from other approaches. This allowed the study of the possible relation between this variable (use of other techniques) and the psychologists' opinion about the tendency to ignore contributions from other theoretical frameworks (readers are reminded that about $90 \%$ of the psychologists admitted the possibility of tending to discredit or ignore contributions from other theoretical outlooks). The results suggest that both variables 
are related, so that the degree of willingness to incorporate techniques from other approaches is congruent with the acceptance of the notion that psychologists tend to make biased valuations of other perspectives.

For a long time, researchers have been interested in the discussion of what promotes patients' change in psychotherapy. Lambert (1986) and Lambert, Shapiro, and Bergin (1986) thought that only $15 \%$ of the change processes in psychotherapy is attributable to specific technical factors and that about $45 \%$ of the change would be attributable to unspecific factors such as the quality of the patient-therapist relationship, the therapist's warmth, acceptance, empathy, commitment, etc. In accordance with this, only a low percentage $(4.41 \%)$ of the participants from the sample thought that the theoretical or technical aspects alone were responsible for patients' change and effective progress, and $54.41 \%$ attributed the change to personal aspects of the therapeutic relationship. Lastly, the relation between the appraisal of change factors in psychotherapy and the belief in the existence of a selective bias in the appraisal of contributions from other theoretical models is significant. In other words, those who say that psychologists tend to be ignorant of the contribution of other theoretical perspectives are more likely to think that the personal aspects such as the therapeutic relationship, the therapist's experience, etc., are responsible for the patients' effective change.

\section{Conclusions and Suggestions}

This study allows one to note, once again, that psychology, and in particular psychotherapy in Argentina, is undergoing a crisis. This crisis is a process of change and of questioning the theoretical and practical nucleus of psychotherapy. Filidoro (2002) thought that, doubtless, psychotherapy in Latin America possesses a fragmented knowledge in all areas because the scientific discoveries and the new technology leave no time for the necessary sedimentation of learning.

In this vast geographical territory, the characteristics of psychotherapy take on their own identity in each one of our countries. In Argentina, the existence of a pronounced critical attitude towards psychotherapy is currently notable. A large percentage of the psychologists of our country have a negative opinion of psychotherapy and most of them believe there is a bias in the appraisal of contributions from other approaches that could contribute with more effective ways to deal with problems.

Professional experience, in terms of years dedicated to practice and, probably, the demands of society and one's own demands to achieve higher effectiveness in psychotherapy, may have favored the tendency to use different techniques in therapy, instead of limiting oneself because of their theoretical origin. Thus, this openness to incorporating techniques from other theoretical approaches is related to psychologists' opinion about selective blindness, which seems to be present in psychotherapists.

Lastly, it is noted that, for most psychologists, personal factors related to the therapeutic relationship such as clinical experience and the therapist's style, are more important than technical factors such as the theoretical model, techniques, and pharmacology. This fact should encourage investigations to distinguish and operationalize these factors and turn them into an efficient working tool.

\section{References}

Alarcón, R. (2002). Estudios sobre psicología latinoamericana. Ricardo Palma University, Lima, Peru: Universitaria.

Buguñá, C. (1993). Docencia en psicoterapia: el proceso de llegar a ser psicoterapeuta en Chile. In G. de la Parra, C. Valdés, \& R. Isla (2001), Enseñanzas de la aplicación de un manual de psicoterapia dinámica para entrenar terapeutas inexpertos en un consultorio externo: resultados finales. Revista Chilena de Neuro-Psiquiatria 39, 121-131.

Eysenck, H.J. (1952). The effects of psychotherapy: An evaluation. Journal of Consulting Psychology, 16, 319-324.

Eysenck, H.J. (1994). Psicoanálisis y terapia de conducta: el error freudiano. Psicología conductual, 2, 149-164.

Fernández Álvarez, H. (1992). Fundamentos de un modelo integrativo en psicoterapia. Buenos Aires: Paidós.

Filidoro, O.J. (2002). Reflexiones sobre la psicoterapia en Latinoamérica. Psicología y psicopedagogía. Publicación virtual de la Facultad de Psicología y Psicopedagogía de la USAL 3, 3.

Ford, D. \& Urban, H. (1998). Contemporary models of psychotherapy. A comparative analysis. New York: Wiley.

Goldfried, M.R. (1985). From cognitive-behavior therapy to psychotherapy integration. New York: Springer. [Spanish translation: De la terapia cognitivo-conductual a la psicoterapia de integración. Bilbao: Desclée de Brouwer, 1996.]

Jiménez, J.P., Florenzano, R., Buguñá, C., Sarnoff, R., \& Vega S. (1991). Descripción del sistema de Servicios de Atención de Psicoterapia en Chile. In G. de la Parra, C. Valdés, \& R. Isla (2001), Enseñanzas de la aplicación de un manual de psicoterapia dinámica para entrenar terapeutas inexpertos en un consultorio externo: resultados finales. Revista Chilena de Neuro-Psiquiatria 39, 121-131.

Karasu, T.B. (1986). The specificity versus nonspecificity dilemma: Toward identifying therapeutic change agents. American Journal of Psychiatry 143, 687-695.

Kohlbercher, V. (1998). Casas inteligentes. New World 3, 31-35.

Lambert, M.J. (1986) Implications of psychotherapy outcome research for eclectic psychotherapy. In J.C. Norcross (Ed.), Handbook of eclectic psychotherapy (pp. 436-462). New York: Brunner/Mazel. [Spanish translation: J.D. Safran \& Z.V. Segal, El proceso interpersonal en la terapia cognitiva. Buenos Aires: Paidós, 1994.] 
Lambert, M.J., Shapiro, D.A., \& Bergin, A.E., (1986). The effectiveness of psychotherapy. In S.L. Garfield \& A.E. Bergin (Eds.), Handbook of psychotherapy and behavior change. (pp. 157-212). New York: Wiley

Larson, D. (1980). Therapeutic schools, styles, and schoolism: A national survey. Journal of Humanistic Psychology 20, 3-20

Opazo, R. (2001). Psicoterapia integrativa. Delimitación clínica. Santiago, Chile: Instituto Chileno de Psicoterapia Integrativa.
Watkins, M. (1986). Invisible guests: The development of imaginal dialogues. Hillsdale, NJ: Analytic Press. [Spanish translation: R. Opazo: Psicoterapia integrativa. Delimitación clínica. Santiago, Chile: Instituto Chileno de Psicoterapia Integrativa 2001.]

Received April 15, 2005 Review received July 13, 2005 Accepted July 21, 2005 